\title{
Migration and Displacement: Legal Constraints of Internally Displaced Persons in Nigeria
}

\author{
Alero Toju Akujobi ${ }^{1}$, Ufuoma Veronica Awhefeada ${ }^{2}$ \\ ${ }^{1}$ Faculty of Law, National Open University of Nigeria, Abujia, Nigeria \\ ${ }^{2}$ Faculty of Law (Oleh Campus), Delta State University, Abraka, Nigeria
}

Email address:

aakujobi@noun.edu.ng (A. T. Akujobi), fuoma2002@yahoo.com (U. V. Awhefeada)

\section{To cite this article:}

Alero Toju Akujobi, Ufuoma Veronica Awhefeada. Migration and Displacement: Legal Constraints of Internally Displaced Persons in Nigeria. International Journal of Law and Society. Vol. 4, No. 3, 2021, pp. 169-176. doi: 10.11648/j.ijls.20210403.13

Received: June 21, 2021; Accepted: July 12, 2021; Published: July 29, 2021

\begin{abstract}
This paper sets out to evaluate how displacement impacts on migration in Nigeria. Displaced persons ordinarily suffer from severe deprivations and precarious living conditions; the outbreak of the COVID-19 pandemic without doubt, worked even more grave hardships on the community of the displaced. This paper ventures into the effects/challenges brought upon displaced persons with regards to the enjoyment and enforcement of human rights and the ability of such persons to abide by the restrictions and regulations guiding conduct of persons during the pandemic. It considers the factors causing displacement and argues that the living conditions of displaced persons leaves them with no option but to disregard the regulations consequent upon the failure of government to put in place enabling conditions that will engender respect and obedience to the regulations. The paper adopts the doctrinal approach and examines the regulations on internally displaced persons (IDPs) through reliance on relevant laws in Nigeria, data collection and existing literature. The paper concludes among others that there is the need for a national legal framework specifically for internally displaced persons that will cater for prevention and management of internal displacement in Nigeria as against the provision of a national policy.
\end{abstract}

Keywords: Displacement, Internally Displaced Persons, Migration, COVID-19 Pandemic, Legal Constraints, National Legal Framework

\section{Introduction}

The challenge of internal displacement and migration is global and has been with humanity from very early times. [1] However, Giustiniani at the end of the cold war, there was an upsurge in the number of displaced persons alongside varying degrees of human rights infractions. [2] Internal displacement is however, more acutely felt in Africa as a result of the wars and violence that has dogged her history. [3] Sub-Saharan Africa hosts some of the largest protracted displacement crises in the world. [4] Emerging conflicts and the effects of climate change forced millions of people to flee from some African states in the year 2020, but many of these crises are overlooked and underfunded. In Nigeria, the impact of internal displacement is vast and enormous. From the decade of colonization when the nation was plunged into bloodletting by the civil war that broke out and lasted for over two years to present times, displacement and migration has been a recurrent decimal. Nigeria has grappled with forced migration mostly due to conflict triggered by ethnoreligious and communal disputes, a civil war in 1967 and other man-made and natural disasters. [5] It is estimated that within one month of the onset of the Nigerian civil war (also known as the Biafran war), for example, over one million displaced persons were evacuated from the northern part of the country to the South East. [6] Nigeria since 2013 has experienced an unprecedented amount of internal displacement due to the insurgency in the Northeast. Nigeria is currently placed as one of the top ten countries with the highest number of internally displaced persons (IDPs) due to conflict - more than in any other African country, ranking fifth with an estimated over 700,000 in 2015 alone. [7]

IDPs in Nigeria are faced with precarious, deplorable and sub-human living conditions. Usually, displaced persons take shelter in camps where they depend on the government and other individuals and organizations to assist with their basic needs of food, water, clothing and shelter. Life in the IDP camps is tough and characterized by deprivations and 
violence. They suffer from gross violations of their human rights and are deprived of the basic necessities of life. With the outbreak of the COVID-19 pandemic, the world was thrown into a state of uncertainty in an attempt to contain the spread of the virus. The World Health Organization reeled out a number of measures to be adopted by states in its COVID-19 Regulations and this was replicated by the government of several states with adaptations to meet the peculiarities of local circumstances. [8] Nigeria joined in the fray of reeling out regulations and restrictions to be observed by citizens at the pain of criminal sanctions. [9] Law enforcement agents also braced up to the challenge of ensuring that the regulations were obeyed. Convictions were secured for breach of the regulations such as those prohibiting public/private gatherings of not more than fifty persons. [10] Although, reference was made to the most vulnerable and even displaced persons, it is doubtful if actual efforts were made by the government to alleviate the plight of displaced persons particularly as pertains to human rights. This paper sets out to examine if the human rights of citizens and especially the displaced and vulnerable persons was taken into consideration in the available regulations. The study observes that IDPs are likely to suffer violation of their human rights within their own country without having any legal or institutional provisions to claim assistance particularly as there is no legal framework in place where they can resort to as a basis for legal remedy.

\section{Statement of Problem}

The need for a legal and institutional framework for addressing the constraints of IDPs is long overdue and should be given special attention. In Nigeria, persons displaced have been forced to migrate from their homelands due to factors beyond their control. [11] Internal displacement brings about a set of circumstances that renders those affected highly vulnerable depriving them of shelter and basic protection. Sadly, the National Policy on Internal Displaced Persons, the National Commission for Refugees, Migrants and Internally Displaced Persons (NCFRMI), the African Union Convention for the Protection and Assistance of Internally Displaced Persons in Africa (otherwise known as the Kampala Convention) of 2009 do not adequately respond to the needs of IDPs much less during pandemics. While the national policy has been identified to be inefficient due to some crippling defects, it has not been passed into law. [12] The Kampala Convention is yet to be domesticated pursuant to section 12 of Nigerian Constitution 1999 (as amended) which demands that any treaty between the Federation and any other country shall have the force of law except to the extent to which any such treaty has been enacted into law by the National Assembly.

The National Commission for Refugees, a statute created for the protection of refugees was extended to include migrants and IDPs and renamed NCFRMI. However, the needed amendment to this extension has not been carried out. The overall effect of an appropriate legislative instrument for the protection of IDPs will foster the constraints experienced by forced migrants. A national legal framework will adequately address the needs of forced migrants or displaced persons, enable them enjoy their human rights without discrimination and seek remedy in the event of violations particularly during the period of pandemic.

\section{Methodology}

The study adopts the doctrinal approach with reliance on primary statutes and secondary methods of data collection such as content analysis, review of online materials, journals and existing literatures. This is with the view of emphasizing the suffering and constraints of IDPs and the need for a national legal framework.

\section{Conceptual Clarification}

According to the International Organization for Migration (IOM), migration is 'movement of a person or group of persons, either across an international border (international migration), or within a state (internal migration), encompassing any kind of movement of people, whatever its length, composition and causes'. The definition is broad and covers all forms of migration (voluntary/forced migration, internal/international migration, long-term/short term). It includes migration of refugees, displaced persons, uprooted people and economic migrants. On the other hand, the term migrant refers to any person who is moving or has moved across an international border or within a state away from his/her habitual place of residence, regardless of the persons legal status, whether the movement is voluntary or not and whatever are the causes for the movement. [13]

This paper however focuses on forced migrants or IDPs who for some factors have found themselves involuntarily in other parts of their country of domicile. The United Nations Guiding Principles on Internal Displacement describes them as:

persons or groups of persons who have been forced or obliged to flee or to leave their homes or places of habitual residence, in particular as a result of, or in order to avoid the effects of armed conflict, situations of generalized violence, violations of human rights or natural or humanmade disasters, and who have not crossed and internationally recognized State border. [14]

Elsewhere, internal displacement has been described as the forced migration of persons from their homeland due to some unpleasant conditions that has affected them or their government could not resolve immediately. [15] Similarly, a duo of learned minds have described internal displacement as situations in which individuals and groups are compelled or obliged to leave their homes, but remain within the borders of their own countries. The latter element differentiates them from refugees, who are also compulsorily evacuated but cross internationally recognized state borders. [16]

The International Organization for Migration established in 1951 defined forced migration as 'a migratory movement 
which, although the drivers can be diverse, involves force, compulsion or coercion'. [17] A combined reading of the above definitions makes it obvious that displacement can lead to migration, and in a sense, migrants can be displaced persons who have found themselves in another region of the country due to push factors beyond their control and have not crossed international borders. They are victims of violence, conflicts, tension and natural disasters that are compelled to seek for abode elsewhere within their country. The terms IDPs is thus wide enough to accommodate migrants who as a result of being displaced, have found themselves in a different region of the country from where they were ordinarily domiciled. This paper, therefore, uses the terms IDPs and forced migrants in the very liberal and loose sense and sometimes interchangeably.

\section{Factors of Displacement of Persons}

A wide range of factors usually account for the displacement of persons. Some of the factors are man-made while others are natural. In the UN Guiding Principles on Internal Displacement as well as under the Kampala Convention for example, armed conflict is identified among the factors which force civilians to flee or leave their homes or places of habitual residence. [18] In Nigeria today for example, it is common knowledge that the Boko Haram indiscriminate attack against civilians including bombing, mass shooting, suicide attack, kidnapping and the destruction of property that has ravaged the north eastern region of the country has left thousands of displaced persons in its trail. States like Borno accounted for 1.5 million of the 2.6 million IDPs recorded in Nigeria in 2019. [19]

Other man made drivers are ethnic and religious tensions in different communities leading to persons fleeing their homes. [20] With the enthronement of the Sharia law in 2000, the country has witnessed myriads of conflicts between the Muslims in the North and Christians in the South leading too many being displaced. The conflicts between herdsmen and farmers have also escalated in recent times triggering more than 53,000 new recorded displacements according to IDMC report 2019.

Suffice to add that infrastructural development, economic and environmental factors such as oil spillage leads to displacement. In 1993, 27 villages were raided, many killed and over 100,000 Ogoni people were displaced as fallout of long standing environmental degradation arising from oil exploration, production and transportation. [21]

According to IDMC report 2019, Nigeria is also highly exposed to natural disasters such as desertification and flooding. The IDMC report stated The flooding is caused by heavy rainfall, overflowing watercourses and release from dam reservoirs. In 2019, floods in the Niger River basin destroyed 2,667 homes in Niger state in August and September leaving about 157,000 new displacements.

Pointedly, Mohammed states that these factors have displaced persons forcing them to migrate to other parts of the country, creating a lot of challenges for the displaced persons. [22]

\section{Effects/Challenges of Displacement}

For persons who have suffered displacement, the challenges are enormous as some take refuge with relatives and friends, others live with host communities. Many others are scattered in different IDP camps in the country while others have as a result of the displacement migrated to neighbouring countries such as Chad, Cameroon, and the Republic of Niger etcetera (IDMC, 2020). [23] In the first half of this year for example, there has been reports of thousands of displaced persons and the figures are deemed conservative due to different techniques of conflicting data collections and restrictions on movement to limit the spread of COVID-19. [24]

Over two thirds of the reported cases in Nigeria are from the north eastern states of Borno, Adamawa and Yobe as a result of violence and attacks on IDP camps. [25] It is reported for example that in the IDP camps in Borno and Adamawa states, the bulk of the victims are women and children who are also the most vulnerable. Sixty-two percent of the IDP populations in these camps are females while thirty-eight percent are male. Half of the total numbers of persons residing in the camps are children under the age of seventeen. A good number of the women are breastfeeding mothers while others are pregnant; a good number of the children are also identified to be unaccompanied and separated. [26]

The movement restrictions and measures being imposed by countries, territories and areas as a response to the pandemic are directly impacting the daily lives and circumstances of IDPs and host communities. Livelihoods are being interrupted and access to healthcare, where it is available, remains limited. Many communities hosting internally displaced populations lack adequate investment in health, water and sanitation facilities, in addition to the issues of overcrowding, poor shelter, scarce resources and limited access to reliable information. According to Adewale, the impact felt by these communities not only increases humanitarian need but also exasperates the existing complex barriers for IDPs to seek solutions. [27] In another report, the number of IDPs in Lagos is reported to be over a hundred thousand facing challenges such as living in slums and under bridges and uncompleted properties. They are often victimized and molested. A majority of them comprise of women and children as well. They face economic vulnerabilities because they do not have a stable source of income. Most of them undertake menial jobs and petty trading.

IDPs were severely affected by the lockdown imposed during the COVID-19 pandemic. They also face health risks from overcrowding; the makeshift shelters they occupy do not allow for them to observe social distancing prevent the spread of COVID-19. For most of the times, they depend on well-meaning individuals and charitable organizations for daily survival. More trying is the incidence of insecurity in 
the camps as the camps are usually invaded by unidentified gunmen and hoodlums who attack and kill the IDPs. There is also the constant threat of eviction by the host communities as some of the landowners of where the camps are located require the use of the land for other purposes.

According to (Olarewaju, Omotosho, Alabi, aside from the lack and deprivation of the basic necessities, other forms of deprivations suffered by IDPs living in camps include family disintegration being a core psychological and social challenge prevalent in some camps. [28] Further, they state that there is the issue of social relations clashes which is reported to be on the increase as well as the disruption of the education of children and other young persons. These challenges have been brought upon them as a result of migrating from the known to the unknown, a situation unanticipated by the displaced persons. Unfortunately, there is no specific legal instrument in place to enforce their rights.

\section{Regulations for Internal Displacement in Nigeria}

IDPs are not stripped of their human rights by virtue of the fact of displacement. Therefore, rights conferred on IDPs can be classed under general and the particular. The general involves rights conferred by enactments entrenching rights enjoyed by every person whether displaced or not. The particular encompasses those rights and privileges specifically provided for in enactments crafted specifically for displaced persons. Consequently, IDPs by virtue of the fact that they are humans enjoy all the rights accruing to citizens under international, regional and domestic human rights instruments as well as those under the Constitution. Therefore, displaced persons in Nigeria enjoy all of the human rights entrenched in the international bill of rights to wit, the Universal Declaration of Human Rights, the International Covenant on Civil and Political rights, the International Covenant on Social, Economic and Cultural Rights and their additional protocols. They also enjoy rights under the African Charter on Human and Peoples Rights which forms part of the body of domestic legislation by virtue of the fact that same has been domesticated. [29] Some of the rights recognised under the African Charter include the right to education, housing, shelter, food, employment, social security, adequate standard of living, safe environment as well as right to cultural life and development. These rights guaranteed under the African Charter has much the same tenor as the fundamental objectives and directive principles of state policy embodied under chapter two of the Nigerian Constitution. Furthermore, IDPs are not precluded in the enjoyment of the fundamental rights conferred on all citizens and persons under the 1999 Constitution. [30] Most of the rights entrenched as fundamental rights reflect the human rights recognized under the International Bill of Rights as well as those under the African Charter on Human and Peoples Rights. These range from the right to life, the right to dignity of the human person, personal liberty, fair hearing, private and family life, to freedom of thought, conscience and religion. Others include the right to freedom of expression and the press, to peaceful assembly and association, freedom of movement, freedom from discrimination, etcetera.

The Constitution however states that the obligations placed on the government in Chapter 11 are however non-justiciable to the extent that the courts do not possess the ability to provide adequate resolution of the dispute. [31] This constitutes a legal constraint on the IDPs when it comes to enforcing their rights in courts.

Aside from the constitutional provisions which embody rights of citizens whether or not displaced, there are a number of other governmental agencies that have duties touching on the assistance and protection of migrants and displaced persons. The National Human Rights Commission for example, has the mandate to promote and protect human rights and ensure discharge of Nigeria's human rights obligation. [32] There is also the National Commission for Refugees, Migrants and Internally Displaced Persons which is the coordinating agency for all IDPs and migration related issues in Nigeria. [33] The National Emergency Management Agency has the duty to manage disaster related issues and coordinate response to all emergencies and provision of relief through the establishment of appropriate structures and measures; this agency without doubt, has a role to play in the assistance to displaced persons as most disasters usually leave in its trail displaced persons. [34] Also, there is the draft national policy on internal displacement which outlines the roles and responsibilities of federal, state and local government and other stake holders and civil society. There is also the National Migration Policy which was adopted May 13, 2015.

The problem is that these agencies have not been effective in carrying out these duties of protecting and assisting the IDPs to ensure they are safe and dignified as noted above, examples abound of displacements and untold hardships suffered by IDPs.

At the international sphere, concerted attempts have been made to adopt a normative framework for the protection and assistance of IDPs. In 1992, the UN Commission on Human Rights entrusted an independent expert to examine the protection afforded under extant international law including human rights law, humanitarian law and refugee law for the protection of IDPs. The committee was of the opinion that IDPs are not sufficiently protected under those laws and that there was the need for an instrument which specifically cater to the needs of IDP and which clearly addresses protection gaps. The work of the committee culminated in the adoption of the United Nations Guiding Principles on internal displacement in 1998 (Guiding Principles) and the establishment of the Inter-Agency Standing Committee on Internally Displaced Persons. [35, 36] Essentially, the Guiding Principles identify rights and guarantees relevant protection of persons from forced displacement and to their protection and assistance during displacement as well as 
during their return or resettlement and reintegration. [37] The Guiding Principles generally restate the fact that IDPs shall enjoy the same rights as other non-IDPs; the principles cover general principle, principles relating to protection from displacement, those relating to humanitarian assistance, and those pertaining to return, resettlement and reintegration. The guiding principles are almost all encompassing in terms of catering for the needs of displaced persons at all stages of displacement; however, the guiding principles is a nonbinding international instrument with only persuasive effect. The Guiding Principles is a commendable effort in terms of standard setting and formed the beginning as it were of international efforts to regulate the issue of IDPs and served as a great influence on other legal instruments that were adopted after it.

At the regional level in Africa, the first major treaty adopted for the purpose of IDPs was the African Union Convention for the Protection and Assistance of Internally Displaced Persons in Africa also referred to as the Kampala Convention. [38] The Convention had the advantage as it were of causing the non-binding Guiding Principles to become binding since it encapsulates in essence, the substance of the Guiding Principles. [39] The Convention provides for the right not to be displaced as well as the duty of state to refrain from, prohibit and prevent arbitrary displacement of populations. [40] But this is almost as far as it goes in terms of the framing of rights of displaced persons. It however places obligations on state parties to the Convention, laying down duties for them in terms of protection from internal displacement as well as duties of the state with regards to protection and assistance to IDPs during internal displacement. It also provides for the duties of armed groups as well as for international and other humanitarian agencies and duties and obligations for the Africa Union itself. State parties also have a duty under the Convention to create satisfactory conditions to facilitate the voluntary return, relocation and reintegration of IDPs. IDPs reserve the right under the Convention to determine whether they wish to return or not. [41] The Convention also provides that IDPs are entitled to appropriate compensation for damages incurred as a result of displacement. [42]

When providing assistance to IDPs, international organizations and other humanitarian agencies are to discharge their obligations in conformity with international law as well as the law of the country in which they operate. Nigeria ratified the Kampala Convention since April 2012 but till date, the National Assembly is yet to pass it into law as an Act of the National Assembly. Hence, it cannot be enforced in any court of law in Nigeria. [43] If and when the convention is passed into law by the National Assembly, it may be of scant legal utility to the IDPs in Nigeria as the provisions do not embody justiciable rights on them but only makes general provisions obliging the government to carry out a number of responsibilities which may lie at the discretion of the government.

\section{IDPS and COVID-19 Regulations: Constraints and Lapses}

As already discussed in the preceding segments of this paper, IDPs are a vulnerable group in the society who already are confronted with a number of existential challenges, ranging from poor makeshift shelters, characterized by overcrowding which impacts greatly on the privacy of IDPs and enjoyment of family life, food and water insecurities, security challenges, exposure of the women to sexual and other forms of abuse, psychological trauma occasion by estrangement from family and loved ones, lack of access of children and young persons to proper education, social relations tensions, economic strangulation among others.

The outbreak of the COVID-19 pandemic served to exacerbate their plight exposing them to the risk of diseases. The sorry situation of displaced persons compels attention and interrogation of whether or not their rights and interests are being taken into consideration by the government in the making and implementation of the COVID-19 Regulations. Without doubt, as already seen above, both in the Regulations made by the President and others, there was mention in general terms of IDPs and the necessity of catering to their needs and ensure their protection. However, beyond the mere mention of IDPs, were concrete steps taken by the government in ensuring their protection as is incumbent upon them by both the Constitution and other international instruments? Is it practicable for example to expect IDPs to observe the regulation requiring social and physical distancing when in actual fact, they live in overcrowded spaces and the government who is under obligation to provide them with shelters have turned a blind eye, virtually, to their plight.

The Constitution for instance provides generally that "the security and welfare of the people shall be the primary purpose of government". [44] It is further provided that the state shall direct its policy towards ensuring that "suitable and adequate shelter, suitable and adequate food..." are provided for all citizens. [45] Both under the African Charter and the Kampala Convention, the right to shelter is recognized as a human right. Nigeria has domesticated the former and is a signatory to the latter. Even though this right to shelter is not a fundamental right under the constitution, the government is under a constitutional obligation to implement the provisions of this chapter of the constitution.

It could therefore be safely assumed that when making the regulations requiring social distancing, the citizens in IDP camps across the nation could not have been within the contemplation of the government in terms of expectation of adherence or enforcement. In stark terms, the failure of the government to provide the basic necessity of shelter to these vulnerable groups of citizen compels them to be oblivious of the law. Therefore, the demand for social distancing and self-isolation in case of contact with suspected infected persons which is at the heart of the regulations to ensure effective containment of the virus, is almost impossible of performance by the IDPs. Under 
chapter 11 of the Constitution, "all persons" are entitled to "adequate medical and health facilities". The implication of this is that IDPs rising from forced migration are covered and entitled to the enjoyment of this provision. It can be said that for IDPs, this is almost an impossible expectation; this is so because non displaced citizens do not even enjoy these benefits in Nigeria. But considered from another angle, it could be said that the IDPs are even more deserving of the enjoyment of these benefits because of their peculiar condition of vulnerability.

The development of any nation today is inextricably tied to the education and potentials of the children and young persons of that country. Before the COVID-19 pandemic, there was no well-structured plan for the education and training of displaced children and young persons who constituted a sizeable percentage of the IDP population. It is a constitutional duty that government shall direct its policy towards ensuring that there are equal and adequate educational opportunities at all levels. Progressively, government is expected to strive to eradicate illiteracy and provide free education at all levels. There is no evidence of even adhoc plans to ensure the education of displaced children. Their education thus having been abruptly disrupted by the events leading up to their displacement, their education hang in the balance until such a time as is possible for their parents to return home and be re-integrated within their communities. There is no certainty as to the length of this period, for example, most of the displaced persons in the north eastern part of the country became displaced as a result of the insurgent activities of the Boko Haram sect, the IDPs sometimes no longer have homes to return to as their entire villages and towns have been razed down and the possibility of their being attacked again remains very high. So for upwards of two years, some persons have lived in IDP camps with no hope of return in sight. For the children displaced along with them, and for those born during the period of displacement, education becomes a far-fetched dream.

Another way in which this lack of education and information impacts negatively is that the children and young persons are not educated or informed, their access to and ability to process vital information is limited as a fall out of compliance to COVID-19. Displaced persons are more often than not, economically handicapped. They do not have a viable means of livelihood and most times depend on the charity of well-meaning individuals and organizations for their sustenance. This also affects their ability to procure basic items such as face masks and sanitizers to protect themselves from contacting the disease.

IDPs suffer untold indignities that touch on the enjoyment and exercise of their fundamental rights. Their right to life, for example, is constantly under threat as a result of the high level of criminality and attacks by bandits that is now a common feature of life in the IDP camps. The dignity of the human person is severely eroded by the sheer indignities suffered as a result of the living conditions. There is no enjoyment of privacy of any sort as displaced persons are forced to live in open classrooms which they share with persons from different backgrounds. The values of familyhood sought to be protected by the fundamental right to private and family life is almost non-existent. The right to personal liberty as well as freedom of movement is severely curtailed.

The COVID-19 Regulation which imposed a lockdown infringed on the right of IDPs to move freely; whether this is justified or not in the circumstance is debatable. This is because, due to the strangulating economic situation IDPs find themselves some of them engage in daily paid menial jobs and petty trading and then return to the camp at night for shelter. By the forced restriction of movement therefore, they became deprived of even this little privilege to help them keep barely afloat.

\section{Recommendations}

Aside the rights that place a direct obligation on government, forced migrants or IDPs still faces a lot of challenges that needs attention to alleviate their hardship. It is hoped that these under-mentioned recommendations if implemented will enhance the plights of these persons.

First, there is the need for a legal instrument that caters specifically for IDPs in conformity with global standards that is coherent and manages all forms of internal displacement in an orderly and equitable fashion. [46] The legal instrument will cater for the prevention, management of internal displacement.

Second, against this backdrop, government must operate on the dynamics of the causes and effects and how to nip them in the bud. For instance, perpetrators of ethnic and religious violence should be fished out, tried and sanctioned to serve as deterrence to others. The legal instrument should contain provisions on sanctions against persons who divert relief materials meant for the IDPs, as well as criminals who take advantage of the vulnerability of IDPs, particularly women and children in the management of IDPs camps.

Third, government should also recognise the interconnectivity in forced and regular migration as an important step in formulating a coherent national legislation. [47]

Fourth, with an increasing number of persons forced to migrate, government and relevant stakeholders should make concerted efforts towards disaster risk, management preparedness in times of emergency and prevention of conflicts through equity and fairness and accountability. [48] This will help effective settlement and assist to achieve economic self- sufficiency.

Fifth, importantly, Nigeria should domesticate the Kampala's Convention for ultimate effect as the Convention has the advantage of causing the non-binding Guiding Principles to become binding encapsulating in essence the substance of the Guiding Principles. The government should create satisfactory conditions to facilitate the voluntary return, relocation and reintegration of the internally displaced persons. By ensuring that facilities in places of conflicts are rebuilt to encourage IDPs to return home. 


\section{Conclusion}

IDPs are persons that have been forced for reasons stated above to migrate and live their homes or place of domicile within their country. They are vulnerable groups in the society who already are confronted with a number of existential challenges. Their humanitarian needs should be given attention to alleviate their sufferings through the enactment of a legal instrument specifically for their needs that provides forced migrants cause of action for compensation in the events of default on the part of the government. This will alleviate the legal constraints on them.

Going by the Global Report on Internally Displaced Persons (GRID), on the 20th anniversary of the Guiding Principles, there are over 30.6 million new displacements associated with conflicts and disasters and this does not call for celebration. There is an urgent need by all stakeholders for a well-structured plan for the protection and assistance of IDPs. Concerted efforts against arbitrary forced migration and durable solutions must be put in place to ensure sustainable development that is equitably distributed to enhance governance respect for human right and secure protection in the long run.

There is no denying the fact that internal displacement is a complex phenomenon deduced by various determinants. It is imperative the Nigerian government cultivates the political will to prosecute, in accordance with all extant laws, everybody engaged in insurgency, terrorism, etcetera as this will uproot the cause of internal displacement

Good laws and policies without the appropriate political will to implement them will remain dead letters. To this extant, the causes of the displacement should be properly addressed and made justiciable so that when government defaults, victims can take up actions for enforcement through an appropriate legal framework.

\section{References}

[1] In the first half of the year 2020 alone, it is reported by the Internal Displacement Monitoring Centre (IDMC) that there are 14.6 million displacements across 127 countries; Internal Displacement 2020: Mid-Year Update, Internaldisplacement.org.

[2] Giustiniani, F. Z., (2009) New Hopes and Challenges for the Protection of IDPs in Africa: The Kampala Convention for the Protection and Assistance of Internally Displaced Persons in Africa Denv. J. Int'l Law 39 (2), 347.

[3] It is on record that in Africa, at least half of the countries and 20 percent of the continent's population have been affected by frequent armed conflicts; see International Federation of Red Cross and Red Crescent Future Priorities in Africa 11 (2004) unpublished manuscript. According to more recent report, of the Internal Displacement Monitoring Centre, sub-Saharan Africa experienced more internal displacement than any other region as over 16.5 million persons were displaced as at the year ended 2018 .

[4] The IDMC mid-year Internal Displacement Report for 2020 for example indicates that ten countries with the highest displacement from conflict and violence, seven are African countries; the countries are Syria, DRC, Burkina Faso, South Sudan, Somalia, Mozambique, Afghanistan, Mali, Yemen and Central African Republic. See Giustiniani, F. Z., (2009) New Hopes and Challenges for the Protection of IDPs in Africa: The Kampala Convention for the Protection and Assistance of Internally Displaced Persons in Africa Denv. J. Int'l Law 39 (2), 347.

[5] In 1966, there was a coup d'état which was closely followed by other politically motivated events and killings; this resulted in the people of the defunct Eastern Region declaring secession from the Federal Republic of Nigeria and proclaiming the independent state of Biafra. This move was fiercely resisted by the federal government; the ensuing war lasted for thirty months.

[6] Orji, K. E., Uebari S. N (2013) Nigerian Civil War and Refugee Crisis: The Fate of the Minorities in The Former Eastern Region IOSR Journal of Humanities and Social Science.

\section{[7] IDMC Africa Report, 2016.}

[8] World Health Organisation COVID-19 Regulations.

[9] See Nigeria's COVID 19 Regulations 2020, made pursuant to sections 2, 3 and 4 of The Quarantine Act, Cap. Q2, Laws of the Federation of Nigeria, 2004, whereby COVID-19 was declared as a dangerous disease.

[10] One of the high-profile convictions secured in this regard was that of the entertainer, Funke Akindele and her husband who were convicted for having a party involving the gathering of over fifty persons and in which social distancing was not observed which was clearly against the COVID-19 regulations. See the Vanguard of April 62020.

[11] E. Mooney (2005) The Concept of Internal Displacement and the Case for Internally Displaced Persons as a Category of Concern' Refugee Survey Quarterly 24) (3), 10.

[12] See Ezenokwasa, Kalu, Okaphor, (2018) A Critique of the Legal Framework for Arresting the Threat of Internal Displacement of Persons to Nigeria's National Security' NAUJIL 9 (2) 20.

[13] See International Migration Law - Glossary on Migration, a publication of the International Organization for Migration $\begin{array}{lllll}\text { Retrieved } & 16 & \text { October } & 2020 & \text { from }\end{array}$ publication.iom.int/system/files/pdf/iml_1_en.pdf.

[14] United Nations Guiding Principles on Internal Displacement, E/CN. 4/1998/53/Add 2, $11^{\text {th }}$ February 1998, paragraph 2; this definition is adopted as well by the African Union Convention for the Protection and Assistance of Internally Displaced Persons in Africa, 2008, also known as the Kampala Convention.

[15] Akume, A. T., (2015) The Question of Internally Displaced Persons (IDPs) in Nigeria: A Reflection on Present Realities, Journal of Third World Studies, 32 (1), 221 at 222.

[16] Aloh and Obaji, (2016) Internal Displacement in Nigeria and the case for Human Rights Protection of Displaced persons, Journal of Law, Policy and Globalization 51, 26.

[17] Is a leading inter-governmental organization in the field of migration and works closely with governmental intergovernmental and non- governmental. 
[18] See paragraph 2 of the UN Guiding Principles as well as Article $1(\mathrm{k})$ of the Kampala Convention.

[19] IDMC REPORT 2019.

[20] Examples are the Itsekiris and Ijaws conflict in 1999, The IfeModakeke rivalries etcetera.

[21] Terminski. B, Oil -Induced Displacement and Resettlement; Social Problem and Human Right Issues' (2012) Retrieved 16 March 2021 from c:/users/user/downloads/docl:26899_741771990.pdf.

[22] See generally, Mohammed, F. K., (2006) The Causes and Consequences of Internal Displacement in Nigeria and Related Governance Challenges, SWP Working Paper, FG 8, April 2017, SWP Berlin; UNCHR, State of the World's Refugees, 2006: Human Displacement in the new millennium 160 .

[23] Conflict between the Fulani pastoralists and Hausa farmers in north west states of Katsina, Sokoto and Zamfara led tens of thousands of people to flee across border into the Maradi region of Niger; as reported by IOM DTM COVID-19 Impact on IDPs, 2 July 2020.

[24] It is reported by the Internal Displacement Monitoring Centre (IDMC) that for the first half of 2020, 8,800 persons were displaced from disasters while 32,000 were displaced from conflict and violence in Nigeria.

[25] International Crisis Group, The Boko Haram Insurgency 2020.

[26] The data for this report are the results of a detailed assessment conducted in 33 sites in Borno and Adamawa in January and February 2015 by the Internal Displacement Monitoring Centre.

[27] COVID-19 Impact on IDPs No. 6 displacement.iom.int.

[28] Olanrewaju, F. O., Omotosho, F., Alabi, J. O., Datasets on the Challenges of Forced Displacement and Coping Strategy among Displaced Women in Selected IDPs Camps in Nigeria, Elsevier, Data in Brief Vol. 2018, 152-158 Retrieved 16 January 2021 from http://doi.org/10.1016/j.dib.2018.07.042.

[29] African Charter on Human and Peoples Rights (Ratification and Enforcement) Act, Cap. A 9, Laws of the Federation of Nigeria, 2004.

[30] Chapter four of the 1999 Constitution of the Federal Republic of Nigeria as amended provides in detail for the fundamental human rights recognized under the constitution.

[31] Chapter two of the Constitution is made non-justiciable vide section 6 (6) (c) which provides that the judicial powers of the state do not extend to any issue question as to whether any act or omission by any government or is in conformity with the fundamental principles.
[32] Established vide the National Human Rights Commission Act, Cap. N. 46 Laws of the Federation of Nigeria, 2004.

[33] This is set up under the National Commission for Refugees, Migrants and Internally Displaced Persons Act, Cap. N 21, Laws of the Federation of Nigeria, 2004.

[34] http://nema.gov.ng/.

[35] UN Doc. E/CN 4/1998/53/Add. 2 (Feb. 11, 1998).

[36] See generally, United Nations, Protecting internally displaced persons: inter-agency standing committee policy paper. New York, 1998, Retrieved 23 February 2021 from http:www.reliefweb.int/idp/docs/references/iascpolicyprotecti onpaper.pdf.

[37] This much was stated in the introductory paragraph of the Guiding Principles on United Nations internal displacement.

[38] Adopted on 23 October 2009, 49 I. L. M., 86. At the subregional level however, there was the Pact on Security, Stability and Development signed in December 2006, by the States in the Great Lakes Region which included two protocols specifically dedicate to the protection of IDPs.

[39] See Kidane W., (2011) Managing Forced Displacement by Law in Africa: The Role of the New Africa Union IDPs Convention. Vanderbilt Journal of Transnational Law, 44, 1 at 6.

[40] See Article 3 (1) (a) of the Kampala Convention.

[41] Article 11 Kampala Convention.

[42] Article 12 Kampala Convention.

[43] By section 12 of the Constitution of the Federal Republic of Nigeria, for any treaty to have the force of law in Nigeria, it must first be passed into law by an Act of the national assembly; see Abacha v. Fawehinmi (2005) 6 N. W. L. R. Part 660 at 240 .

[44] Section 14 (2) (b) of the 1999 Constitution as amended.

[45] Section 16 (2) (d) of the 1999 Constitution as amended.

[46] The legislation in place presently tends to cater more for refugees than for IDPs. e.g The 1951 Refugee Convention.

[47] Forced migration has a distinctive character but under contemporary conditions of global mobility and mixed migration flow, it is not a completely separate phenomenon from regular migration.

[48] Such as Non-Governmental Organisations (NGOS), Host Communities and Individuals. 